\title{
Correction: Introduction to comments on 'Outsourcing: how to reform WHO for the 21st century'
}

Abimbola S. Introduction to comments on 'Outsourcing: how to reform WHO for the 21st century'. BMJ Global Health 2017;2:e000272.

The title of this article is incorrect. The correct title is: 'Comment-WHO is badly in need of reform, but NGOs like our own cannot replace it'.

Open Access This is an Open Access article distributed in accordance with the Creative Commons Attribution Non Commercial (CC BY-NC 4.0) license, which permits others to distribute, remix, adapt, build upon this work noncommercially, and license their derivative works on different terms, provided the original work is properly cited and the use is non-commercial. See: http://creativecommons.org/licenses/by-nc/4.0/

BMJ Global Health 2017;0:e000272corr1. doi:10.1136/bmjgh-2016-000272corr1 